Acta vet. scand. 1986, 27, 103-114.

From the National Veterinary Institute, Oslo, Norway.

\title{
A COMPARISON OF SELENOMETHIONINE AND SODIUM SELENITE AS A SUPPLEMENT IN CHICKEN FEEDS
}

\author{
By \\ Knut Moksnes and Gunnar Norheim
}

\begin{abstract}
MOKSNES, KNUT and GUNNAR NORHEIM: A comparison of selenomethionine and sodium selenite as a supplement in chicken feeds. Acta vet. scand. 1986, 27, 103-114. - Fifty Norwegian-bred White Leghorn chickens, 20 weeks of age, were divided into 3 groups and fed a basal diet containing $0.09 \mathrm{mg} \mathrm{Se} / \mathrm{kg}$ dry matter (D.M.). One group was given a supplement of $0.5 \mathrm{mg}$ Se/ $\mathrm{kg}$ as seleno-DL-methionine (Se-Met), another group $0.5 \mathrm{mg} / \mathrm{kg}$ as sodium selenite while one group served as control. After 10 weeks, all 3 groups were offered the basal diet without added selenium (Se) for a further 9 weeks. At the end of the supplementation period, significantly higher Se levels in blood and tissues were observed in the Se-Met group. These higher levels were not reflected in the glutathione peroxidase (GSH-Px) activity. During the first weeks of the depletion period, there was a steady decrease in Se levels and GSH-Px activity in blood and tissues in both the Se supplemented groups. However, Se levels in the group receiving sodium selenite fell almost to those in the control group after 2 weeks, while the levels in the Se-Met group did not approach the control levels, even after 9 weeks. There were no differences as regards tissue GSH-Px activity between the 2 supplemented groups, which in both groups nearly reached the control level after 2 weeks. There was, however, a more rapid decrease in GSH-Px activity in whole blood in the sodium selenite group from week 0 to 5 as compared to the Se-Met group. The results obtained in this study support the theory that different forms of Se occupy separate metabolic pools in the body, and that the Se pool resulting from Se-Met supplementation can be mobilized for GSH-Px synthesis in a depletion period.
\end{abstract}

glutathione peroxidase; bioavailability; active selenium; depot effect.

Previous studies have shown that supplementation of selenomethionine (Se-Met) in feed results in higher tissue levels of selenium (Se) than when the same amount of Se is added as sodium selenite. This is also seen with Se of plant and animal origin which mainly consists of Se-Met (Olson et al. 1970, Ku et al. 1972, Kääntee \& Kurkela 1980). There are, however, species 
differences. In chickens, Se-Met induces higher tissue levels than sodium selenite when both are given at levels equivalent to 0.1 $\mathrm{mg} \mathrm{Se} / \mathrm{kg}$ feed, while in lambs, the supplement must be increased to above $0.5 \mathrm{mg} \mathrm{Se} / \mathrm{kg}$ before a corresponding effect is observed (Moksnes \& Norheim 1982, 1983, Moksnes 1983). The present experiment was designed to study whether the higher tissue Se levels which result from the use of Se-Met in chickens will act as a Se pool in a Se depletion phase, and be available for glutathione peroxidase (GSH-Px) synthesis.

\section{MATERIALS AND METHODS}

Fifty Norwegian-bred White Leghorn chickens 20 weeks of age, were divided into 3 groups. The birds were individually caged and fed a basal feed containing $0.09 \mathrm{mg} \mathrm{Se} / \mathrm{kg}$ dry matter (DM) (Table 1). Prior to the start of the experiment, the chickens were fed standard compound mixtures of concentrates containing about $0.35 \mathrm{mg} \mathrm{Se} / \mathrm{kg}$. Twenty birds were fed the basal diet supplemented with $0.5 \mathrm{mg} \mathrm{Se} / \mathrm{kg} \mathrm{DM}$ as sodium selenite (Group 1). Another 20 birds were given a supplement of $0.5 \mathrm{mg}$ $\mathrm{Se} / \mathrm{kg} \mathrm{DM}$ as seleno-DL-methionine (Group 2), while 10 chickens served as controls (Group 3). The period of selenium supplementation lasted 10 weeks, after which the depletion period started (week 0 ) as all birds were offered the basal diet with no Se added for a further 9 weeks. Heparinized blood samples were collected at the start of the supplementation period, and again after a period of 5 weeks. Further blood samples were collected at the start of the depletion period and after 1, 2, 5 and 9 weeks. Two birds from the control group and 4 birds from each of the 2 supplemented groups were slaughtered at the start of the depletion period and after 1, 2, 5 and 9 weeks. Samples of liver,

T a b le 1. Composition of the basal feed.

\begin{tabular}{lr}
\hline Ground barley & $67.2 \%$ \\
Ground maize & $8.3 \%$ \\
Mitsubishi single cell protein & $14.5 \%$ \\
Standard mineral mixture & $9.5 \%$ \\
Standard vitamin premix & $0.5 \%$ \\
Content: & \\
Digestible crude protein & $16.0 \%$ \\
Selenium & $0.09 \mathrm{mg} / \mathrm{kg}$ \\
\hline
\end{tabular}


and cardiac and breast muscle were collected for analysis. Five eggs from each group were randomly selected each week during the depletion period. The whites and yolks were separated before pooling and blending.

No difference concerning egg production and egg weight could be detected between the 3 different groups during the experimental period.

\section{Analytical methods}

Blood and tissue samples were analysed for Se content and GSH-Px activity while eggs were analysed for Se only. Samples of liver, and cardiac and breast muscle in which total and Se dependent GSH-Px activity were to be determined were immediately frozen in liquid nitrogen and kept below $-80^{\circ} \mathrm{C}$ until they were analysed. Samples for Se analysis were frozen at $-20^{\circ} \mathrm{C}$ immediately after collection. Material for analysis was taken in a semifrozen state to prevent loss of fluid from the samples. Samples of whole blood for determination of Se and GSH-Px activity were refrigerated for analysis the following day. Selenium was determined by a fluorimetric method after digestion with nitric and perchloric acid (Ihnat 1974, Norheim \& $\mathrm{Ny}$ moen 1981). Total and Se dependent GSH-Px activity were determined using cumene hydroperoxide and hydrogen peroxide as substrates, respectively (Paglia \& Valentine 1967, Moksnes \& Norheim 1983). Results are expressed as $\mu \mathrm{kat} / \mathrm{l}(\mathrm{kg})$ and $\mu \mathrm{g}$ $\mathrm{Se} / \mathrm{ml}$ (g) wet weight, respectively. The statistical analyses used are $t$-test and linear regression carried out according to MSTAT (Nissen 1982).

\section{RESULTS AND DISCUSSION}

\section{Selenium levels and GSH-Px activity in blood}

After 5 weeks of the supplementary period Se levels and GSH$P x$ activities in blood were considerably higher in both experimental groups compared to the initial levels (Fig. 1). At the end of the supplementary period, after 10 weeks, the Se levels in the selenite group and the GSH-Px activity in the Se-Met group were almost the same as at the start of the supplementation period.

During the same 10 weeks these same 2 parameters fell to about one third of the base-line (initial) levels in the unsupple- 

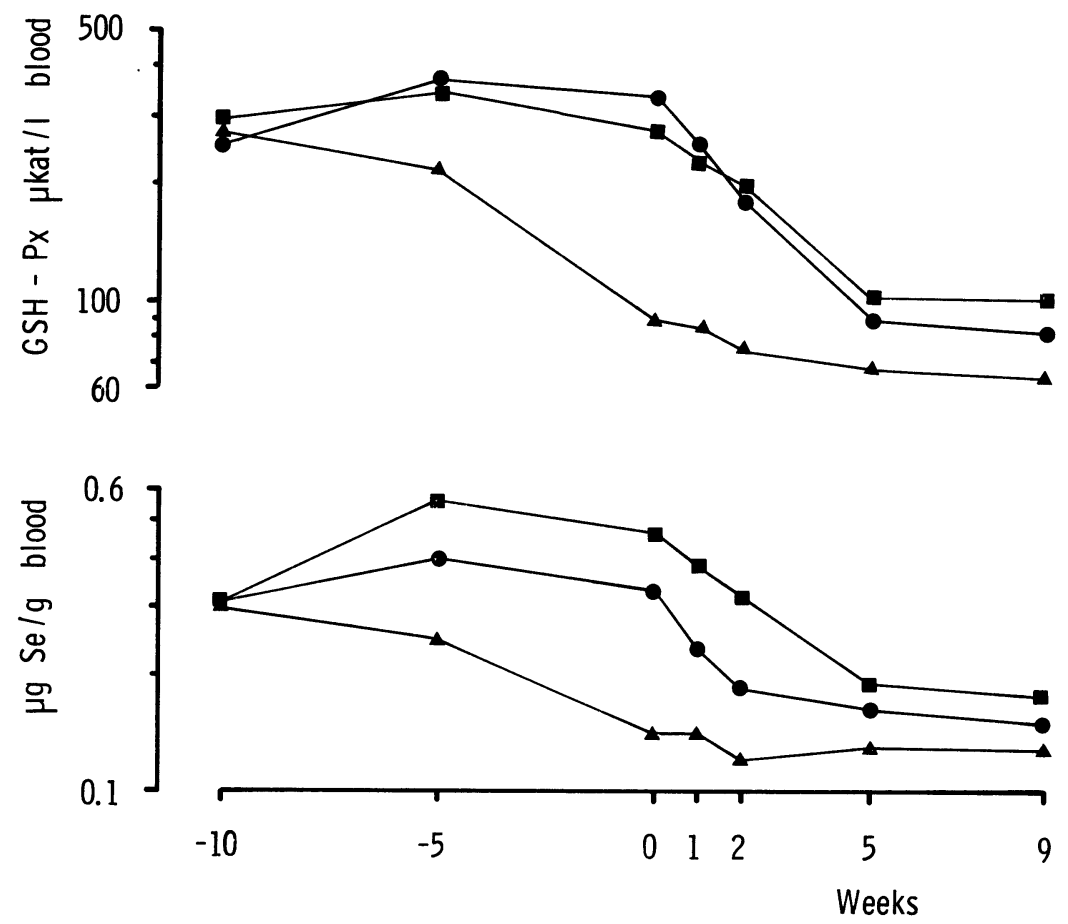

Figure 1. Effect of selenium supplementation on blood selenium levels $(\mu \mathrm{g} \mathrm{Se} / \mathrm{ml})$ and GSH-Px activities ( $\mu \mathrm{kat} / \mathrm{l})$ in chickens after supplementation of the feed with $0.5 \mathrm{mg} \mathrm{Se} / \mathrm{kg}$ for 10 weeks. Selenium sources were sodium selenite $(\bigcirc)$, selenomethionine $(\square)$, and control (A). The absolute standard deviations for selenium ranged from 0.01 to $0.05 \mu \mathrm{g} \mathrm{Se} / \mathrm{g}$ blood, and for GSH-Px activities from 6 to $61 \mu \mathrm{kat} / 1$ blood.

mented control group. The decrease in blood Se and GSH-Px activity seen in the experimental groups are difficult to explain, but may indicate that Se levels in the feed were insufficient to maintain the high levels obtained previous to a period of increasing egg production.

During the entire supplementary period, blood Se levels were significantly higher in the Se-Met group than in the selenite group $(\mathrm{P}<0.001)$. These findnigs are in agreement with results from previous studies in which natural Se from Se-rich fish meal, wheat and soybean meal, as well as sodium selenite, were used as Se sources (Scott \& Thompson 1971). Corresponding differences in blood GSH-Px activity were not observed. On the 
contrary, the selenite group showed the highest activity ( $\mathrm{P}<$ 0.001 ) at the end of the supplementary period. This discrepancy in blood Se compared to GSH-Px activity found between the 2 experimental groups, indicates that some of the Se detected in blood in the Se-Met group had not been incorporated into active GSH-Px. This finding may probably be explained by the fact that Se-Met has two alternative fates in the body: either it can be incorporated into body proteins in the place of methionine, or it can be catabolized to release Se, which in time will be available for GSH-Px synthesis (Carry et al. 1973, Sunde et al. 1981). Inorganic Se, however, does not result in an accumulation of Se-Met in these tissues when fed to monogastric animals (Cummins \& Martin 1967, Jenkins 1968). A greater part of the Se detected in blood after selenite supplementation thus seems to be available for GSH-Px synthesis. These results support the theory that organic and inorganic Se occupy separate metabolic pools in the body (Levander et al. 1983).

During the first 5 weeks of the depletion period, the level of blood GSH-Px activity in the experimental groups approached that in the controls, most rapidly in the selenite group. When using a semilogarithmic plot, the correlation coefficients in the selenite and Se-Met groups were $r=-0.94$ and $r=-0.92$, respectively, enabling us to calculate the regression coefficient for the elimination rate from week 0 to 5 , being -0.017 in the selenite group and -0.013 in Se-Met group, corresponding to half lives of $t_{\frac{1}{2}}=18$ and $t_{\frac{1}{2}}=24$ days, respectively. The regression coefficients were significantly different $(P<0.001)$. These results indicate that Se-Met supplementation induces a pool of Se in tissues which subsequently may be released and used in GSH-Px synthesis.

These findings are in agreement with the results reported by Levander et al. (1983) who studied the availability of Se from different sources in man. They found that the platelet GSH-Px activity decreased more rapidly in the depletion period in the group supplemented with inorganic Se as compared to the group receiving organic Se.

The regression coefficient for the elimination rate of Se from blood in the period from week 0 to 5 was calculated for the Se-Met group to $-0.011(\mathrm{r}=-0.94)$, corresponding to a half life of 27 days. In the selenite group, however, the curve was only linear in the period from week $0-2(r=-0.91)$. The 
regression coefficient for this period was calculated to -0.017 , corresponding to $t_{\frac{1}{2}}=18$ days.

\section{Selenium levels and GSH-Px activity in organs}

At the beginning of the depletion period, distinct differences in Se levels and GSH-Px activities were observed between the different organs, liver tissue showing the highest and breast muscle the lowest values (Fig. 2 and Table 2). Within each organ, the Se-Met group showed much higher Se levels than the selenite group. As regards breast muscle, the Se levels in the selenite group were only about $25 \%$ of those in the Se-Met group, while the corresponding figures for heart muscle and liver were $50 \%$ and $60 \%$ respectively. Simliar differences in GSH-Px activity could not be detected. The two supplemented groups are therefore combined in Table 2. The higher Se levels in the SeMet group therefore do not contribute to the GSH-Px activity, and selenium levels in this case do not give an adequate estimate of the physiological Se status of the body. A firm conclusion as to whether these tissue deposits derived from Se-Met serve as an important long-term source of Se as body proteins turns over cannot be reached on the basis of the present experiment, because of the short duration of both the repletion and depletion period and the limited number of animals. Slightly longer halflife of the blood GSH-Px activity in the Se-Met group, however, indicates such an effect in the first few weeks. On the other hand, higher organ concentrations of Se without corresponding higher GSH-Px activity, were detected throughout the whole depletion period. Only small differences between total and Sedependent GSH-Px activities were observed throughout the depletion period. In liver, and cardiac and breast muscle, the average Se-dependent activity was $81 \pm 8,94 \pm 5$ and $87 \pm 7$ per cent of the total enzyme activity, respectively, when considering all chickens analysed (Table 2). Similar results have been observed in ducklings (Xu \& Diplock 1983). Schäfer et al. (1982) demonstrated that the percentage of Se-dependent GSH-Px is dependent upon the amount of Se in the feed, varying from $0 \%$ in Se-depleted hens to $82 \%$ in hens receiving a supplement of $0.9 \mathrm{mg} \mathrm{Se} / \mathrm{kg}$ feed. In sheep, the proportion of total GSH-Px in liver which is dependent upon Se is smaller, varying from $22 \%$ when the feed contained $0.13 \mathrm{mg} \mathrm{Se} / \mathrm{kg}$ to $54 \%$ when the feed contained $1.3 \mathrm{mg} \mathrm{Se} / \mathrm{kg}$ (Moksnes \& Norheim 1983). 

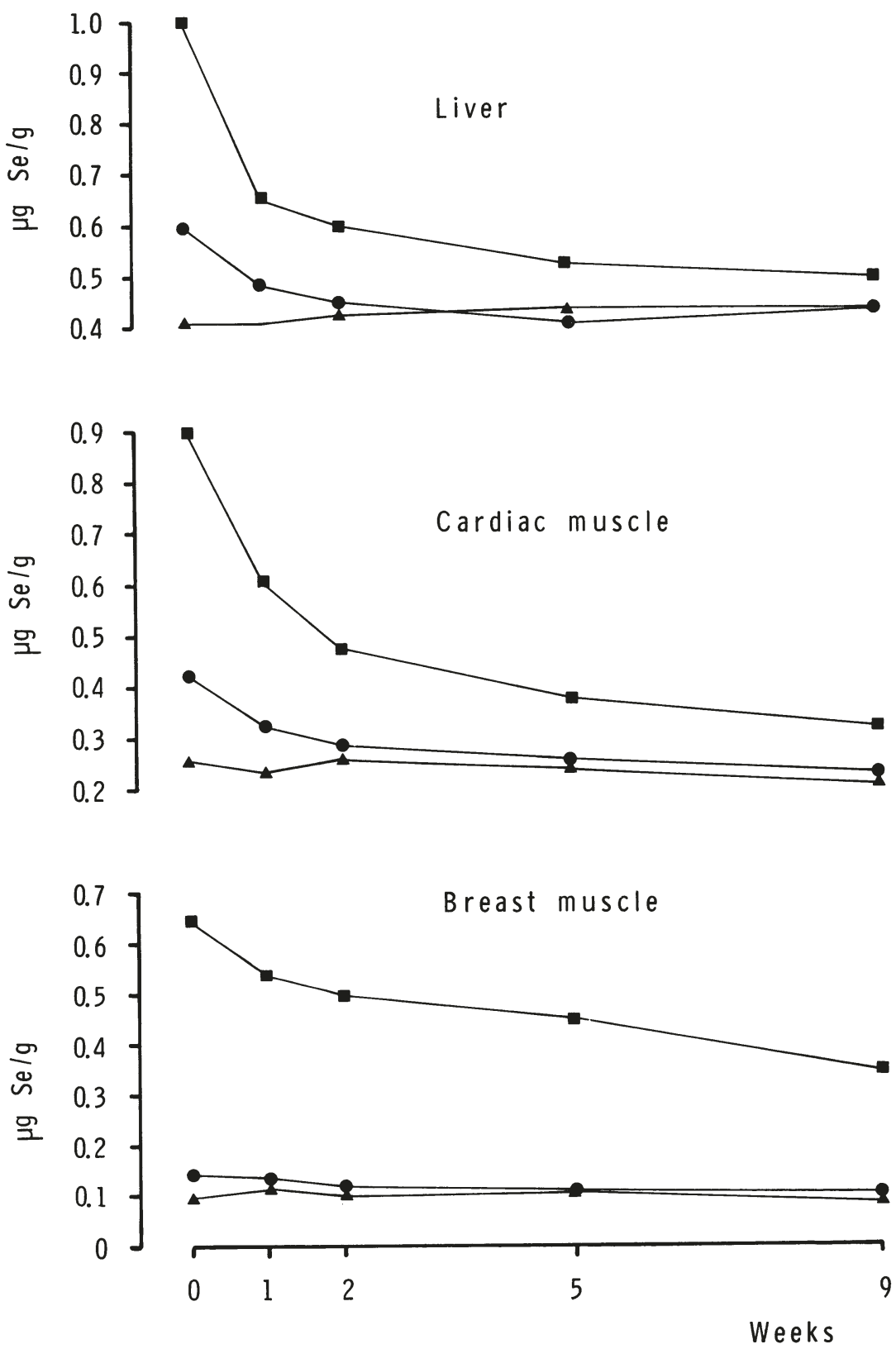

F i g u r e 2. Effect of selenium supplementation on liver and cardiac and breast muscle selenium levels ( $\mu \mathrm{g} \mathrm{Se} / \mathrm{g}$ wet weight) of chickens. See Fig. 1 for explanation. 


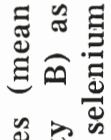

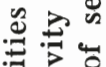

氜

$\times$ 苛苍

状造这

过 。

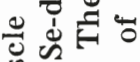

串

을

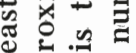

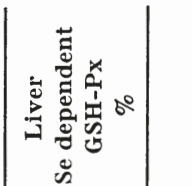

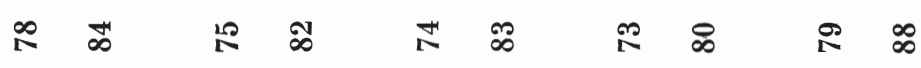

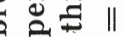

돋

สิ

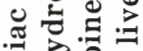

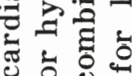

दे

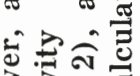

$\exists$ ฮ

5.

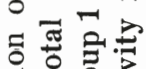

氜

造的

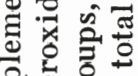

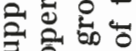

क

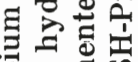

ฮ웡

㣢

¿

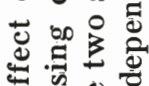

प्र

है

จ

$0 \approx$

$2-5$

๙

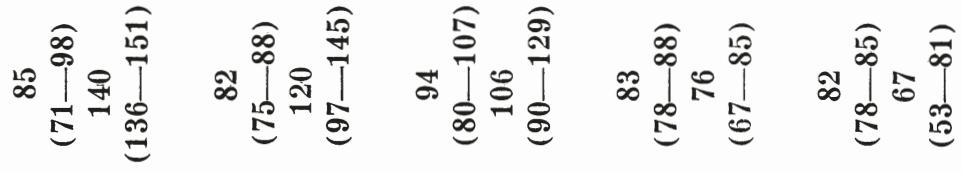

\&i

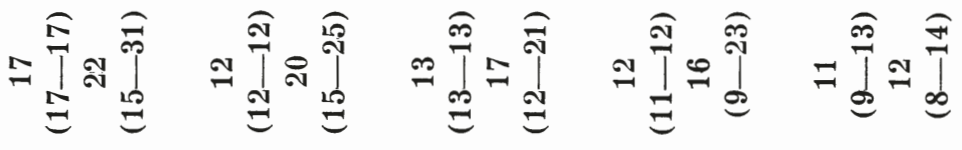

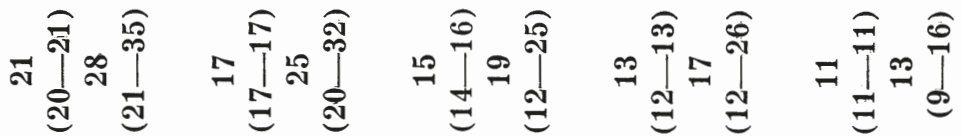

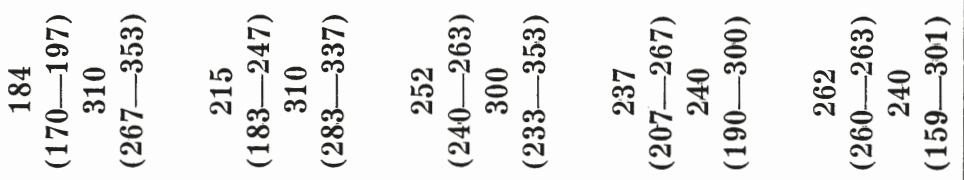

空

$=$
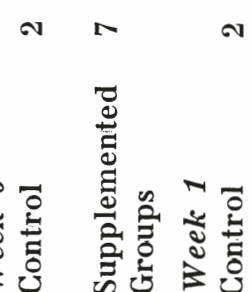

$$
\infty
$$

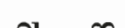

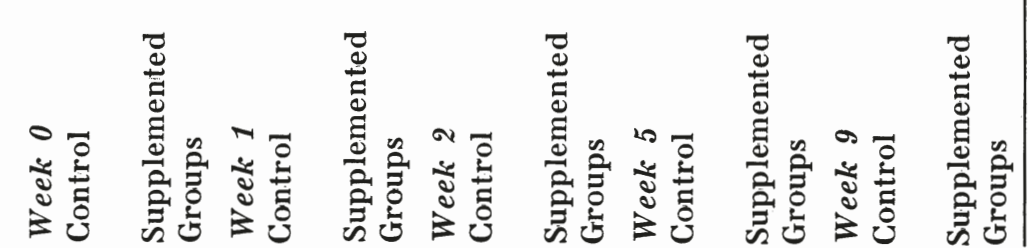

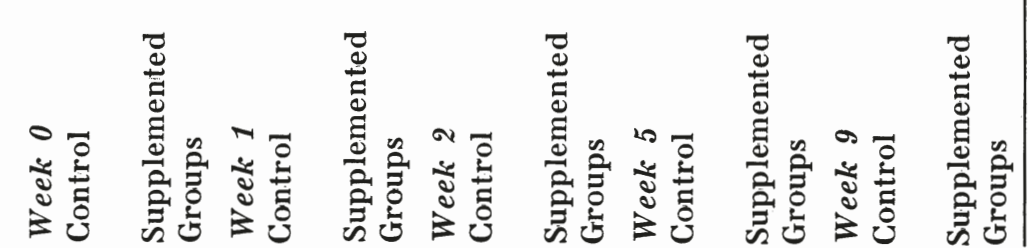

N $\infty$ 
At the end of the experiment the enzyme activity in the Sesupplemented groups was less than in the control group. This may be explained by the observation that animals on low Se intake can utilize Se better for GSH-Px than animals on higher levels (Sandholm et al. 1981).

\section{Selenium in eggs}

At the start of the depletion period, there were significant differences between egg Se levels in the 3 groups, this being especially true for the egg whites (Table 3). A rapid decrease in the Se level followed during the depletion phase, reaching the control level after 2 weeks in egg white and egg yolk in the sodium selenite group (Group 1) and after 4 weeks in yolk in the Se-Met group (Group 2). From week 4 to 9 , the rate of decrease levelled off. The excretion of Se through egg white was prolonged in the Se-Met group, levels not falling to the control level even after 9 weeks of depletion. This prolonged excretion may be due to a slower protein turnover in the precursor pools used for egg white synthesis as compared to egg yolk. The excretion pattern seen here is in contrast to the results obtained by Kääntee \& Kurkela (1980) who observed a sharp drop in egg white Se during the initial depletion phase which then rose before again declining slowly to the basal level. This discrepancy may be due to different Se sources and to the short feeding period (only 4 weeks) as compared with the present experiment.

T a b l e 3. Effect of selenium supplementation on egg yolk and egg white selenium levels ( $\mu \mathrm{g} \mathrm{Se/g}$ wet weight).

\begin{tabular}{|c|c|c|c|c|c|c|c|c|c|c|c|}
\hline & & \multicolumn{10}{|c|}{ Weeks } \\
\hline & & 0 & 1 & 2 & 3 & 4 & 5 & 6 & 7 & 8 & 9 \\
\hline \multirow{2}{*}{$\begin{array}{l}\text { Group } 1 \\
\text { (Selenite) }\end{array}$} & Egg yolk & 0.81 & 0.41 & 0.33 & 0.33 & 0.38 & 0.35 & 0.38 & 0.43 & 0.32 & 0.30 \\
\hline & Egg white & 0.13 & 0.05 & 0.06 & 0.05 & 0.04 & 0.06 & 0.09 & 0.06 & 0.05 & 0.06 \\
\hline \multirow{2}{*}{$\begin{array}{l}\text { Group } 2 \\
\text { (Se-Met) }\end{array}$} & Egg yolk & 0.99 & 0.74 & 0.48 & 0.42 & 0.38 & 0.39 & 0.35 & 0.36 & 0.30 & 0.35 \\
\hline & Egg white & 0.65 & 0.26 & 0.14 & 0.11 & 0.10 & 0.10 & 0.14 & 0.08 & 0.09 & 0.09 \\
\hline \multirow{2}{*}{$\begin{array}{l}\text { Group } 3 \\
\text { (Control) }\end{array}$} & Egg yolk & 0.31 & 0.32 & 0.30 & 0.33 & 0.34 & 0.36 & 0.35 & 0.33 & 0.29 & 0.34 \\
\hline & Egg white & 0.05 & 0.05 & 0.05 & 0.04 & 0.04 & 0.06 & 0.05 & 0.05 & 0.05 & 0.06 \\
\hline
\end{tabular}




\section{CONCLUSION}

There is a closer relationship between Se concentrations and GSH-Px activity in different organs in chickens supplemented with sodium selenite than in those supplemented with Se-Met. The higher Se concentration in blood and tissues obtained with Se-Met is in agreement with the observation that Se-Met can be incorporated into general body proteins without contributing to the GSH-Px activity. In this case, the Se levels do not give an adequate estimate of the physiological Se status of the body. Though the short duration and small scale of this experiment do not allow any firm conclusions to be drawn, the results nevertheless support the theory that different forms of Se occupy separate metabolic pools in the body, and that the Se pool formed after Se-Met supplementation can be mobilized for GSHPx synthesis during a Se depletion period. As assessed by blood and organ tissue GSH-Px activity, there is no clear indication that Se-Met is superior to sodium selenite as a feed additive to prevent Se deficiency in chickens.

\section{REFERENCES}

Cary, E. E., W. H. Allaway \& M. Miller: Utilization of different forms of dietary selenium. J. Anim. Sci. 1973, 36, 285-292.

Cummins, L. M. \& J. L. Martin: Are selenocystine and selenomethionine synthesized in vivo from sodium selenite in mammals. Biochemistry 1967, 6, 3162-3168.

Ihnat, M.: Fluorimetric determination of selenium in foods. J. Ass. off. anal. Chem. 1974, 57, 368-372.

Jenkins, $K$. J.: Evidence for the absence of selenocystine and selenomethionine in the serum proteins of chicks administered selenite. Canad. J. Biochem. 1968, 46, 1417-1425.

Kääntee, E. \& P. Kurkela: Comparative effects of barley feed and sodium selenite on selenium levels in hen eggs and tissues. J. Sci. agric. Soc. Fin. 1980, 52, 357-367.

Ku, P. K., W. T. Ely, A. W. Groce \& D. E. Ullrey: Natural dietary selenium, $\alpha$-tocopherol and effect on tissue selenium. J. Anim. Sci. 1972, 34, 208-211.

Levander, O. A., G. Alfthan, H. Arvilommi, J. K. Huttunen, M. Kataja, P. Koivistoinen \& J. Pikkarainen: Bioavailability of selenium to Finnish men as assessed by platelet glutathione peroxidase activity and other blood parameters. Amer. J. clin. Nutr. 1983, $37,887-897$.

Moksnes, K.: Selenium deposition in tissues and eggs of laying hens given surplus of selenium as selenomethionine. Acta vet. scand. $1983,24,34-44$. 
Moksnes, K. \& G. Norheim: Selenium concentrations in tissues and eggs of growing and laying chickens fed sodium selenite at different levels. Acta vet. scand. 1982, 23, 368-379.

Moksnes, $\boldsymbol{K}$. \& G. Norheim: Selenium and gluthatione peroxidase levels in lambs receiving feed supplemented with sodium selenite or selenomethionine. Acta vet. scand. 1983, 24, 45-58.

Nissen, Ø.: Statistikkprogram for CP/M-maskiner. (Statistics programme for $\mathrm{CP} / \mathrm{M}$ machines). Norges landbrukshøgskole, Inst. for plantekultur, Melding $\mathrm{nr} .202,1982,55 \mathrm{pp}$.

Norheim, G. \& U. K. Nymoen: Fluorimetric determination of selenium in biological material using automatic digestion. 8th Nordic Trace Element and Microchemistry Conference, Sandefjord, Norway, June 10-13, 1981.

Olson, O. E., E. J. Novacek, E. I. Whitehead \& I. S. Palmer: Investigations on selenium in wheat. Phytochemistry $1970,9,1181-1188$.

Paglia, D. E. \& W. N. Valentine: Studies on the quantitative and qualitative characterization of erythrocyte glutathione peroxidase. J. lab. clin. Med. 1967, 70, 158-169.

Sandholm, V., S. Sankari, S. Østerberg \& F. Atroshi: Selenium independent variation of erythrocyte glutathione peroxidase activity in Finnsheeps. Proc. Mineral Elements '80, Helsinki, Finland 1981, p. 487-496.

Schäfer, K., K. Männer \& K. Bronsch: Einfluss von Selenzulagen auf die Glutathion-Perioxidase Aktivitäten in Erythrozyten, Plasma und Leber bei Jung- und Legehennen. (Influence of selenium supplement on glutathione-peroxidase activities in erythrocytes, plasma and liver of young and laying hens). Zbl. Vet. Med. A, 1982, 29, 271-278.

Scott, M. L. \& J. N. Thompson: Selenium content of feedstuffs and effects of dietary selenium levels upon tissue selenium in chicks and poults. Poult. Sci. 1971, 50, 1742-1748.

Sunde, R. A., G. E. Gutzke \& W. A. Hoekstra: Effect of dietary methionine on the biopotency of selenite and selenomethionine in the rat. J. Nutr. $1981,111,76-86$.

Xu, G. L. \& A. T. Diplock: Glutathione peroxidase (EG 1.11.1.9), glutathione-S-transferase (EC 2.5.1.13), supéroxide dismutase (EC 1.15.1.1) and catalase (EC 1.11.1.6) activities in tissues of ducklings deprieved of vitamin $\mathrm{E}$ and selenium. Brit. J. Nutr. 1983, 50, 437-444.

\section{SAMMENDRAG}

En sammenligning av selenomethionin og natriumselenitt som tilsetning i hønefór.

Femti verpehøns ble delt i 3 grupper og gitt et grunnfór som inneholdt $0,09 \mathrm{mg} \mathrm{Se} / \mathrm{kg}$ (tørrvekt). En gruppe ble gitt et tilskudd på $0,5 \mathrm{mg} \mathrm{Se} / \mathrm{kg}$ som seleno-DL-methionin (Se-Met). En annen gruppe fikk $0,5 \mathrm{mg} \mathrm{Se} / \mathrm{kg}$ som natriumselenitt, mens en gruppe tjente som kontroll. Etter 10 uker fikk alle 3 gruppene kun grunnfór uten Se til- 
setning. På dette tidspunkt var Se nivåene i Se-Met gruppen signifikant $h \varnothing y e r e$ enn $i$ de andre gruppene. Det $h \varnothing y e r e$ Se nivået gjenspeilte seg ikke i glutationperoksydase (GSH-Px) aktiviteten. I løpet av de første ukene etter at Se tilskuddet ble fjernet sank Se nivåene og GSH-Px aktiviteten i begge gruppene som hadde fått Se tilskudd. Se nivåene i natriumselenittgruppen sank nesten til nivået i kontrollgruppen allerede etter 2 uker, mens nivået i Se-Met gruppen ikke nådde dette nivået selv etter 9 uker. Det var ingen forskjell mellom de to gruppene med hensyn til GSH-Px aktiviteten i organene som nesten nådde det samme nivåt som $\mathrm{i}$ kontrollgruppen etter 2 uker. I blod avtok GSH-Px aktiviteten fra uke $0-5$ raskere i natriumselenittgruppen enn i gruppen som hadde fått Se-Met. Resultatene fra dette fors $\varnothing$ ket støtter teorien om at Se fra forskjellige Se kilder kan gå forskjellige metabolske veier i kroppen og at Se reservoaret som er en følge av tilskudd med Se-Met kan bli tilgjengelig for GSH-Px syntese i en periode uten Se tilskudd.

(Received December 20, 1985).

Reprints may be requested from: Knut Moksnes, Apothekernes Laboratorium A.S, P. O. Box 158 Sk $\varnothing$ yen, N-0212 Oslo 2, Norway. 